THEORIES OF DISTINCTION 

Cultural Memory

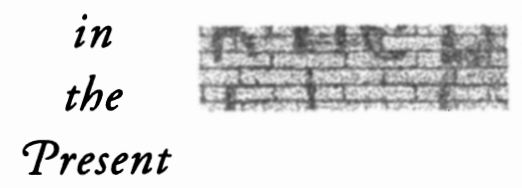

Mieke Bal and Hent de Vries, Editors 



\title{
THEORIES OF DISTINCTION
}

\section{Redescribing the Descriptions of Modernity}

\author{
Niklas Lubmann \\ Edited and introduced \\ by William Rasch
}

Translations by Joseph O'Neil, Elliott Schreiber, Kerstin Behnke, and William Whobrey

STANFORD UNIVERSITY PRESS

STANFORD, CALIFORNIA

2002 
Stanford University Press

Stanford, California

C 2002 by the Board of Trustees of the

Leland Stanford Junior University

Library of Congress Cataloging-in-Publication Data

Luhmann, Niklas.

Theories of distinction : redescribing the descriptions of modernity I

Niklas Luhmann ; edited and introduced by William Rasch ; translations by

Joseph O'Neil ... [et al.].

p. cm. - (Cultural memory in the present)

Includes bibliographical references and index.

ISBN 0-8047-4122-0 (alk. paper)-ISBN 0-8047-4123-9 (pbk.)

I. Sociology-Philosophy. 2. Social sciences-Philosophy. 3. Participant

observation-Philosophy. 4. Knowledge, Sociology of. I. Rasch, William, 1949-

II. Title. III. Series.

HM 585.2842002

$301^{\prime} .01-\mathrm{dc} 21$

2001049220

Original Printing 2002

Last figure below indicates year of this printing:

$\begin{array}{llllllllll}\text { II } & 10 & 09 & 08 & 07 & 06 & 05 & 04 & 03 & 02\end{array}$

Typeset by G \& S Typesetters in 11/13.5 Adobe Garamond. 